\title{
Analysis of the Status of China's OFDI to ASEAN and the Suggestions for Investment
}

\author{
Xin-Ying LIU ${ }^{1, a}$ and Shen-Ying-Jie ZHANG ${ }^{2, b,{ }^{*}}$ \\ ${ }^{1}$ Department of International Economics and Trade, Shandong University of Finance and \\ Economics, Jinan, Shandong Province, 250014, China \\ ${ }^{2}$ Department of International Economics and Trade, Shandong University of Finance and \\ Economics, Jinan, Shandong Province, 250014, China \\ aemail: sheila_guo1988@hotmail.com, bemail:zhangshenyingjie@163.com
}

Keywords: China-ASEAN, foreign direct investment, suggestions.

\begin{abstract}
With the increase of the degree of globalization, China's foreign direct investment has been growing. ASEAN is an important economic partner of China, also occupies a very important position in "The Belt and Road". This paper makes use of descriptive statistics to analyze the current situation of China's foreign direct investment. We did research on ten ASEAN countries, including Malaysia, Indonesia, Thailand, Philippines, Singapore, Brunei, Vietnam, Laos, Burma and Kampuchea. And we put forward relevant suggestions according to the current situation and existing problems of China's foreign direct investment.
\end{abstract}

\section{Introduction}

With the increasing level of China's economic development and closer economic ties between China and ASEAN, China's OFDI to ASEAN has also been developing rapidly in recent years. In 2009, China and ASEAN signed the investment agreement on China-ASEAN Free Trade Area, making the cross-border investment of both enterprises more convenient and free, which provided a good opportunity for Chinese enterprises to invest directly in ASEAN countries. In 2010, China ASEAN formally launched the free trade area, which made the market of ASEAN more open and eliminated some of the original investment barriers, which created more favorable conditions for the economic exchanges between China and ASEAN. In the trend of globalization, the links between countries and regions are increasingly close, economic cooperation in the Asia Pacific region are deepening. ASEAN is the third largest trading partner of China. Studying the present situation of China's direct investment to ASEAN and putting forward relevant suggestions based on the findings, and then optimizing China's foreign direct investment is a very significant research topic.

\section{The status of China's OFDI}

Compared with 2015, the global economic growth rate declined in 2016, and the growth rate of the developed economies decreased significantly, and the growth rate of emerging and developing economies rebounded. International trade remains low, and various uncertainties, such as Britain's removal from Europe, have made the international financial markets more volatile and unstable. After a strong rise in 2015, global FDI lost momentum in 2016, and the annual outflow rate dropped by $2 \%$. Tired in the global environment, China foreign direct investment is showing rapid growth. Since 2003, China's foreign direct investment has been growing for 14 consecutive years. In 2016, the traffic volume was 72.6 times that of 2002. The share of the world increased from $0.5 \%$ in 2002 to $13.5 \%$, and its position and role in the global foreign direct investment is increasingly prominent. The average annual growth rate of 2002-2016 years is up to 35.8\%. In 2016, China's foreign direct investment exceeded the foreign investment (134 billion U.S. dollars) again, and the net output of capital under two-way direct investment was realized for two years in a row.

In 2016, the flow of China's foreign direct investment flows to Asia was 130 billion 270 million U.S, dollars, accounting for $66.4 \%$ of the current foreign direct investment flow. Among them, the 
investment to HongKong was 114 billion 230 million U.S, dollars, an increase of $27.2 \%$ over the same period, accounting for $87.7 \%$ of investment in Asia, and a 10 billion 280 million investment in ASEAN countries, a decrease of $29.6 \%$ over the same period last year, accounting for $7.9 \%$ of Asian investment. The investment in the remaining parts of the Latin American region was 27 billion 230 million U.S, dollars, accounting for 13.9\%. The flow of investment to North America was 20 billion 350 million U.S, dollars, accounting for 10.4\%. Investment in Europe is 10 billion 690 million U.S, dollars, accounting for 5.4\%. The investment in Oceania was 5 billion 210 million U.S, dollars, accounting for 2.7\%. Investment in Africa is 2 billion 400 million U.S, dollars, accounting for $1.2 \%$.

The data are shown in Table1, in 2016, the amount of China foreign direct investment stock and flow data are ranked second, occupies a very large proportion in the total amount of Chinese in foreign direct investment, so it is very meaningful to research the present situation of China's OFDI to ASEAN.

Table1 China's investment in major economies in 2016

\begin{tabular}{|c|c|c|c|c|c|}
\hline \multirow{2}{*}{ Economies } & \multicolumn{3}{|c|}{ Flows } & \multicolumn{2}{c|}{ Stocks } \\
\cline { 2 - 6 } & $\begin{array}{c}\text { Sum(100 } \\
\text { billion U.S. } \\
\text { dollars) }\end{array}$ & $\begin{array}{c}\text { on } \\
\text { year-on-year } \\
\text { basis(\%) }\end{array}$ & Percentage(\%) & $\begin{array}{c}\text { Sum(100 } \\
\text { billion } \\
\text { U.S. } \\
\text { dollars) }\end{array}$ & Percentage(\%) \\
\hline HongKong & 1142.33 & 27.2 & 58.2 & 7807.45 & 57.5 \\
\hline EU & 99.94 & 82.4 & 5.1 & 698.37 & 5.1 \\
\hline ASEAN & 102.79 & -29.6 & 5.2 & 715.54 & 5.3 \\
\hline U.S.A & 169.81 & 111.5 & 8.7 & 605.80 & 4.5 \\
\hline Australia & 41.87 & 23.1 & 2.1 & 333.51 & 2.4 \\
\hline Russia & 12.93 & -56.3 & 0.7 & 129.80 & 1.0 \\
\hline Total & 1569.67 & 26.3 & 80.0 & 10290.47 & 75,8 \\
\hline
\end{tabular}

\section{The Status of China's OFDI to the Belt and Road}

China government actively promoting the construction of "The Belt and Road ". China is steadily developing international capacity cooperation. China's "going out" work system has been constantly improved and the active integration of Chinese enterprises into the process of economic globalization has accelerated.

Table2 2005-2015 The stock of China’s OFDI to ASEAN and “The Belt and Road”

\begin{tabular}{|c|c|c|c|}
\hline Year & $\begin{array}{c}\text { China's } \\
\text { OFDI(Billions } \\
\text { of } \\
\text { U.S.dollars) }\end{array}$ & $\begin{array}{c}\text { China's } \\
\text { OFDI to } \\
\text { “The Belt } \\
\text { and Road” } \\
\text { (Billions of } \\
\text { U.S.dollars) }\end{array}$ & $\begin{array}{c}\text { China's OFDI to } \\
\text { ASEAN(Billions } \\
\text { of U.S.dollars) }\end{array}$ \\
\hline 2005 & 572 & 44.2532 & 12.5615 \\
\hline 2006 & 906.3 & 63.7847 & 17.6338 \\
\hline 2007 & 1179.1 & 113.8201 & 39.5317 \\
\hline 2008 & 1839.7 & 162.1036 & 64.8699 \\
\hline 2009 & 2457.5 & 209.8779 & 85.7142 \\
\hline 2010 & 3172.1 & 308.2543 & 143.5021 \\
\hline 2011 & 4247.8 & 443.7117 & 214.617 \\
\hline 2012 & 5319.4 & 616.4195 & 282.3754 \\
\hline 2013 & 6604.8 & 790.744 & 356.6835 \\
\hline 2014 & 8826.4 & 988.0004 & 476.3253 \\
\hline 2015 & 10978.6 & 1228.2675 & 623.5532 \\
\hline
\end{tabular}

It can be seen from Table2, stocks of China's OFDI to ASEAN for all "The Belt and Road" country's foreign direct investment stock proportion is close to $50 \%$, that is to say Chinese enterprises into the ASEAN member countries to invest in nearly half of the "The Belt and Road" 
country's investment. Therefore, we conclude that ASEAN plays a very important role in "The Belt and Road ". Therefore, it is of great significance to carry out a more thorough and comprehensive study of the factors that affect the economic development of China and ASEAN.

\section{The Status of China's OFDI to ASEAN}

In 2016, China's investment flows to ASEAN countries were 10 billion 279 million US dollars, down $29.6 \%$ from the same period last year, accounting for $5.2 \%$ of total investment flows, accounting for $7.9 \%$ of Asian investment flows, and the stock amounted to 71 billion 554 million US dollars, accounting for $5.3 \%$ of the total stock volume, accounting for $7.9 \%$ of Asian investment stocks. In 2016, China's investment in Singapore amounted to 3 billion 172 million US dollars, down 69.7\% from last year's (10 billion 452 million US dollars), and its investment in Malaysia, Vietnam and Thailand increased rapidly.

We collated the distribution data of the investment stock of China to ASEAN in 2016, and the conclusion was shown in Table3.

Table3 The main industry of China's OFDI to ASEAN in 2016 (ten thousand U.S. dollars)

\begin{tabular}{|c|c|c|c|c|}
\hline Industry & Flows & Percentage(\%) & Stocks & Percentage(\%) \\
\hline Manufacturing & 354,370 & 34.5 & $1,314,969$ & 18.4 \\
\hline Leasing and business services & 137,106 & 13.3 & $1,122,250$ & 15.7 \\
\hline Mining & 24,119 & 2.3 & $1,016,925$ & 14.2 \\
\hline Wholesale and retail & 196,304 & 19.1 & 968,975 & 13.5 \\
\hline $\begin{array}{l}\text { Power/heat/gas and water } \\
\text { production and supply }\end{array}$ & 66,424 & 6.5 & 912,135 & 12.7 \\
\hline Finance & 45,400 & 4.4 & 457,319 & 6.4 \\
\hline Construction business & 63,487 & 6.2 & 450,678 & 6.4 \\
\hline Agriculture/forest/Pastora/Fisheries & 37,370 & 3.6 & 313,845 & 4.4 \\
\hline Realty industry & 124,590 & 12.1 & 198,793 & 2.8 \\
\hline $\begin{array}{c}\text { Transportation/storage and postal } \\
\text { services }\end{array}$ & $-67,010$ & -6.5 & 182,306 & 2.5 \\
\hline $\begin{array}{l}\text { Scientific research and technical } \\
\text { service industry }\end{array}$ & 7,364 & 0.7 & 71,912 & 1.0 \\
\hline $\begin{array}{l}\text { Information transmission/software } \\
\text { and information services }\end{array}$ & 19,125 & 1.9 & 60,017 & 0.8 \\
\hline $\begin{array}{c}\text { Residents' services/repairs and } \\
\text { other services }\end{array}$ & 15,515 & 1.5 & 56,598 & 0.8 \\
\hline $\begin{array}{l}\text { Accommodation and catering } \\
\text { industry }\end{array}$ & 1,759 & 0.2 & 11,977 & 0.2 \\
\hline $\begin{array}{l}\text { Culture/sports and entertainment } \\
\text { industry }\end{array}$ & 3,149 & 0.3 & 7,917 & 0.1 \\
\hline $\begin{array}{l}\text { Water conservancy/environmental } \\
\text { and public facilities management }\end{array}$ & $-1,877$ & -0.2 & 6,954 & 0.1 \\
\hline Education & 581 & 0.1 & 1,660 & 0.0 \\
\hline Other industries & 92 & 0.0 & 179 & 0.0 \\
\hline Total & $1,027,868$ & 100.0 & $7,155,409$ & 100.0 \\
\hline
\end{tabular}

From the overseas enterprises in the country (region) distribution, the number of Chinese in Asia of foreign enterprises set up nearly 2.1 million, accounting for $55.8 \%$, mainly distributed in HongKong, Singapore, Japan, Korea, Vietnam, Indonesia, Laos, Arabia, United Arab Emirates, Thailand, Kampuchea, Malaysia, Mongolia. As a result of the restriction of the database, we have arranged the number of China's investment in ASEAN from 1980 to 2013, as shown in Table4. 
Table4 1980-2013 The number of China's enterprises investment in ASEAN

\begin{tabular}{|l|l|l|l|}
\hline Country & Number & Country & Number \\
\hline Singapore & 616 & Laos & 510 \\
\hline Malaysia & 290 & Kampuchea & 303 \\
\hline Indonesia & 517 & Vietnam & 806 \\
\hline Burma & 166 & Brunei & 15 \\
\hline Thailand & 375 & Philippines & 157 \\
\hline
\end{tabular}

\section{Suggestion}

Based on the analysis of the present situation of China's OFDI to ASEAN, this paper puts forward the following suggestions for Chinese enterprises to invest in ten ASEAN countries:

First, ASEAN's national composition is relatively special, and the gap of economic development between countries is relatively large. Singapore, Malaysia and Thailand are relatively well-developed, and Laos, Kampuchea and Burma are relatively backward in economic development. The unique national structure makes the market development of ASEAN economies have an obvious gradient division. This provides a broad space for Chinese enterprises to invest directly in ASEAN, so that diversified industries in China can find suitable investment targets. Because of the different speed of the national economic development, some industries in China are in the stage of overcapacity and phasing out. But if these industries are transferred to the less developed countries in ASEAN, they may regain the comparative advantage and stimulate the vitality of the industry. Therefore, we suggest that this part in our country has lost competitive advantage but still has the comparative advantage of the industrial transfer to the host country for production in ASEAN economically backward countries, so that both can be external to our sunset industry extension, extend the industrial life cycle, but also to transfer excess domestic production, optimize the allocation of resources. Facing the more developed economies of ASEAN economies, we suggest that China choose to invest directly in industries with high technology added value. Because in the developed countries, the development of ASEAN higher level of industry competition is more intense, China's high-tech value-added industry can continue to hone in cooperation with the local industry competition, absorb advanced technology related industries of the host country through foreign direct investment, and learn to use these technologies for domestic industry upgrade.

Second, we suggest that domestic enterprises can carry out both import and export trade and foreign direct investment at the same time. Enterprises first use the import and export trade to familiarise themselves with the host country's market environment and understand the host country's business operation information and policies. After mastering enough information, they choose to invest directly in the suitable host country. Enterprises have low import and export trade cost, less risk, more information and speed, which can help business managers quickly understand the host country's market environment, political environment, local consumption habits and consumption preferences. The managers make full use of the information that they can obtain and then decide whether to invest directly in the host country.

Third, we suggest that domestic enterprises engaged in infrastructure construction can invest directly in these countries with imperfect infrastructure. Because the industrial development level of the less developed countries in ASEAN economies is relatively low, and with the gradual development of the country, the demand for improved infrastructure and advanced technology and equipment has also increased dramatically. China's infrastructure construction strength is in the world's leading position, so in this field, ASEAN has provided a broad market for our enterprises. Chinese enterprises can make full use of their technological advantages and distance advantages with ASEAN to invest in infrastructure development in less developed ASEAN countries, such as building highways, railways and bridges. With the gradual increase of economic exchanges between China and ASEAN and closer economic relations, the access scope of foreign capital between the two big economies is also expanding. In the future, Chinese enterprises will have opportunities to invest directly in Telecom, finance, healthcare and other service industries. 
Fourth, ASEAN countries have different political systems and different levels of economic development. There is still a big gap between the more developed countries and the less developed countries. The economic base of the backward countries in ASEAN is weak, the industrial structure is lagging behind, and the infrastructure is also relatively backward. Some countries lack perfect economic policies and regulatory systems, and even there are conflicts between ethnic groups and the central government. These factors will cause instability in the political environment. These instability impeded the domestic economic development of the host country, and at the same time increased the risk of direct investment. Therefore, we suggest that when making direct investment in those countries with unstable factors, we should pay attention to controlling investment risks and avoiding unnecessary losses.

Fifth, strengthening information exchange through government behavior. From the statistical data, most of China's direct investment in ASEAN has gone to the more developed economies in the ten countries, such as Singapore and Indonesia. Most of the information that China knows is from these economically developed countries. The acquisition of information in backward countries is unilateral and incomplete. It makes it difficult for the decision-makers of multinational enterprises to obtain complete information and data reference, and increase the risk and difficulty of direct investment. Therefore, we suggest that our government can take corresponding measures to open up information channels, and help domestic policymakers of foreign investment enterprises get more information easily. Now China has established ASEAN Business Council, the Chinese government can assist the Business Council and other agencies and chambers of Commerce, collect information, open access to information channels, the China businesses in ASEAN market environment have a better understanding of the enterprise, promote Chinese direct investment to asean. At the same time, the government should also simplify the examination and approval administrative procedures of small and medium-sized private enterprises' overseas investment, shorten the examination and approval period, and actively guide private enterprises to invest abroad with their own funds.

\section{Acknowledgement}

This research was financially supported by Research on the effect of trade Optimization based on China's OFDI to “The Belt and Road”(17BJL014), China's economic and financial system reform(The Ministry of education's brand course for foreign students' English Teaching in China in 2013), and Shandong University of Finance and Economics International Exchange and cooperation special-Course internationalization project International business major and the Prague University of economics, Czech.

\section{References}

[1] Buckley. P.J., Clegg. L.J., Cross, A.R., Liu .X. ,Voss. H. ,Zheng .P. The Determinants of Chinese Outward Foreign Direct Investment, J. Journal of International Business Studies,2007,38(4).

[2] Dunning, J. Toward an Eclectic Theory of International Production: Some Empirical Tests, J. Journal of International Business Studies,1980,(11):9-13.

[3]Yong-Hua FANG. The present situation and Countermeasures of Chinese enterprises to invest in ASEAN, in Chinese, J. Market modernization, 2006.(5).

[4]Yuan-Peng ZHANG, Yong YANG. The factors influencing the location choice of China's foreign direct investment, in Chinese, J. World economic and political forum,2010,(6).

[5] Vernon, R. International Investment and International Trade in the Product Cycle,J. Quarterly Journal of Economics,1966,(80):190-207. 
[6] Johanson, J, L.Vahlne. The Internationalization Process of the Firms: a Model of Knowledge Development and Increasing Foreign Market Commitments, J. Journal of Regional Science, 1997, $37(2)$.

[7]Ru-Qing ZHANG. An analysis of the relationship between China's foreign direct investment and foreign trade, in Chinese, J. World Economy Study,2005,(3):23-27.

[8]Ming-Yong LAI, Qun BAO, Shui-Jun QUN, Xin ZHANG. Foreign direct investment and Technology Spillover: a study based on absorptive capacity, in Chinese, J. economic study,2005,(8). 